Crop Breeding and Applied Biotechnology 12: 277-280, 2012

Brazilian Society of Plant Breeding. Printed in Brazil

NOTE

\title{
Pollen grain germination and fruit set in 'Brazilian seedless' sugar apple (Annona squamosa L.)
}

Hellenn Thallyta Alves Mendes ${ }^{1}$, Márcia Regina Costa ${ }^{1}$, Silvia Nietsche ${ }^{1 *}$, João Alison Alves Oliveira ${ }^{1}$ and Marlon Cristian Toledo Pereira ${ }^{1}$

Received 2 May 2012

Accepted 2 August 2012

\begin{abstract}
The purpose of this study was to evaluate fruit set and pollen grain germination of 'Brazilian seedless' sugar apple. Two experiments were performed: 1) one in a completely randomized design with three treatments (natural and artificial pollination and self-fertilization), with three replications of 10 flowers per plot, 2) and the other in a completely randomized design with three treatments: pollen grains of a seeded wild-type, 'Brazilian seedless' and atemoya (hybrid of sugar apple and cherimoya) 'Gefner', with five replications. A fruit set of 100\% was achieved by artificial pollination. No fruit formation was observed after self-fertilization. The percentage of pollen grain germination in vitro was highest for 'Brazilian seedless' (52.5\%) and lowest for cultivar Gefner (5.9\%). Preliminary results indicated that pollen grains of 'Brazilian seedless' are viable and that natural or artificial pollination is essential for fruit set.
\end{abstract}

Key words: Seedless fruit, atemoya, artificial pollination.

\section{INTRODUCTION}

In Brazil there are few well-established breeding programs for sugar apple (also known as custard apple). Several cultivars have been developed including 'Thai Lessard' (a green type), 'Purple' or 'Red', 'Kampong Mauve' (purplishred types), and spontaneous seedless types known under different names, e.g., 'Thai seedless', 'Cuban seedless' and 'Brazilian seedless' (Crane et al. 2005). According to Lora et al. (2011), as Annona fruits do not normally develop parthenocarpically, hand pollination is commonly used to ensure complete fertilization in commercial production.

The absence of seeds in fruits can be a result of two biologically distinct processes: parthenocarpy and stenospermy (Revers 2006). Parthenocarpy may occur in cases where the ovary is able to develop without fertilization of the oosphere, whereas stenospermy is reported in cases where pollination and fertilization are required, but embryos are either not formed or are aborted before complete seed formation (Stout 1946, Varoquaux et al. 2000). A recent study described the unique case of seedless fruit production in a mutant of Annona squamosa, 'Thai seedless'. According to the authors, this mutant represents a particular case of stenospermocarpy, resulting in a failure in seed development as the ovules or embryos get aborted (Lora et al. 2011).

Despite being morphologically perfect, neither self or cross-pollination takes place effectively in Annona spp.. Selfpollination is hindered by the presence of protogyny, whereas cross-pollination by insects is limited because the flowers are not brightly colored and lack fragrance and nectar (Kahn et al. 1994, Pena et al. 2002). The low fruit set observed in species of the Annonaceae family is associated with aspects involving source of pollen grains and pollen grains viability (Saaveedra 1977, Rosell et al. 1999). Several studies have shown how strongly pollination with viable pollen grains affects the physical and chemical characteristics of cherimoya, custard apple and atemoya (Sulikeri et al. 1975, Kishirsagar et al. 1976, Soria et al. 1990, Pereira et al. 2003).

Considering the total absence of scientific studies on 'Brazilian seedless' mutant sugar apple, this work was performed with the objective of evaluating the fruit set by natural, artificial and self-fertilization and studying the pollen grain germination in this mutant.

\footnotetext{
${ }^{1}$ Universidade Estadual de Montes Claros, Departamento de Ciências Agrárias, Campus de Janaúba, Reinaldo Viana 2630, 39.440-000, Janaúba, MG, Brazil. *E-mail: silvia.nietsche@unimonte.br
} 


\section{MATERIAL AND METHODS}

'Brazilian seedless' mutant sugar apple, a wild-type sugar apple accession (P2), and atemoya (a hybrid of sugar apple (Annona squamosa) and cherimoya (Annona cherimola) cultivar Gefner) were planted on an experimental farm in March 2004. Plants and rows were spaced $3 \mathrm{~m}$ and $4 \mathrm{~m}$ apart, respectively, and irrigated by a micro sprinkler system. All recommended cultural practices were applied throughout the growth period.

The experiments were performed during March and April, 2009. The plants were properly identified and the flowers covered with paper bags before reaching the pistillate stage. The artificial pollination was performed when the flowers of 'Brazilian seedless' sugar apple reached the pistillate stage. Then, pollen grains were collected in the staminate stage and artificially pollinated with a brush number two, from 8:00 to 9:00 am. Thereafter, the flowers were covered again to keep pollinating insects away. For self-pollination, the flowers were wrapped in paper bags before reaching the pistillate stage and maintained in the wrapping until the end of the period of pistillate flowers. The natural pollination was performed by tagging pistillate flowers that were left without any protection to allow insect pollination. All treatments were applied in the same plant. The experimental design was completely randomized with three treatments (self-pollination, natural pollination and artificial pollination), with three replications. A total of 30 flowers per treatment were evaluated. The percentage of fruit set was obtained by counting the total number of fruits 20 days after pollination. The physiochemical characteristics of fruits were not performed due to the high incidence of fruit borer (Cerconota annonela) that attacked and damaged the fruits.

Five flowers of each genotype were harvested. Pollen grains from 'Brazilian seedless' sugar apple, a wild-type sugar apple accession (P2), and atemoya cultivar Gefner were collected from staminate flowers at 7:00 am and immediately placed in plastic bags and sent to the laboratory of Biotechnology. The in vitro germination tests were performed in culture medium $\left(5 \mathrm{~g} \mathrm{~L}^{-1}\right.$ agar, $1.27 \mathrm{mMCa}\left(\mathrm{NO}_{3}\right)$ $24 \mathrm{H}_{2} \mathrm{O}, 0.87 \mathrm{mM} \mathrm{MgSO}_{4} 7 \mathrm{H}_{2} \mathrm{O}, 0.99 \mathrm{mM}$ and $1.62 \mathrm{mM}$
$\mathrm{KNO}_{3} \mathrm{H}_{3} \mathrm{BO}$ (Brewbaker and Kwack 1963) at $\mathrm{pH} 7.0$ and $100 \mathrm{~g} \mathrm{~L}^{-1}$ sucrose. After autoclaving the medium $\left(121^{\circ} \mathrm{C}\right)$, $10 \mathrm{~mL}$ aliquots were distributed on Petri dishes. The pollen grains of each genotype were distributed on the surface of the medium with a brush (number one) to promote a uniform distribution. Then, the Petri dishes were placed in a biological oxygen demand (BOD) incubator, in the dark, at controlled temperature $\left(25 \pm 1^{\circ} \mathrm{C}\right)$ for 6 hours. After this period, 100 pollen grains were counted per Petri dish with a magnifying glass (Ken-A-Vision-3310). Pollen grains were considered germinated when the tube length was equal to or greater than the diameter of the pollen grain. The experimental design was completely randomized with three genotypes, five replications and two Petri dishes per plot. The data were subjected to analysis of variance at $5 \%$ probability, using the statistical program SAEG (Euclydes 1983). Averages of temperature, air humidity and time of pollen grain collection are described in Table 1.

\section{RESULTS AND DISCUSSION}

No fruit set was observed when flowers of 'Brazilian seedless' sugar apple (Table 2) were self-pollinated. Souza et al. (2010) also reported the absence of fruit set after selfpollination in seedless sugar apple.

The results of this study and of others published by Souza et al. (2010) and Lora et al. (2011) suggest that for fruit production, the mutant seedless sugar apple depends on the stimulation by natural or artificial pollination.

Artificial and natural pollination promoted higher levels of fruit set, $100 \%$ and $90 \%$, respectively (Table 2 ). Different percentages of fruit set were observed in Annona spp. In $A$. cherimola, the fruit set was $84 \%$ to $96 \%$ with selfpollen, but a reduction was observed with mixed pollen, $38 \%$ to $69 \%$ (Richardson and Anderson 1996). Duarte and Escobar (1998) showed a 4,7\% of fruit set in cherimoya when pollen grain from atemoya was used. Studies conducted by Melo et al. (2002) in São Paulo state, which evaluated the natural and artificial pollination of cherimoya flowers, reports percentages of fruit set of 61.2 and $19.6 \%$, respectively. Cavalcante et al. (2009) obtained fruit set rates

Table 1. Percentage of pollen germination of the 'Brazilian seedless', sugar apple accession (P2), and atemoya cultivar Gefner

\begin{tabular}{lcccc}
\hline Cultivars & Pollen Germination (\%) & Temperature $\left({ }^{\circ} \mathrm{C}\right)$ & Humidity $(\%)$ & Time of pollen collection \\
\hline Brazilian Seedless & $52.5 \mathrm{a}$ & 27.2 & 43 & $7: 00$ \\
Sugar apple (P2) & $38.5 \mathrm{a}$ & 26.0 & 44 & $7: 00$ \\
Gefner & $5.9 \mathrm{~b}$ & 26.0 & & 7400 \\
$\mathrm{CV}$ & 27.49 & & & \\
\hline
\end{tabular}

Averages followed by the same letter do not differ from each other by the Tukey test at $5 \%$ probability. 
of $31.1 \%, 4.65 \%$ and $0 \%$ by artificial, natural and selfpollination in Annona crassiflora. The high percentage of fruit set by natural and artificial pollination observed in this study may be related to environmental conditions such as the high temperatures during the experiment, presence of pollinating insects and pollen viability.

Table 2. Percentage of fruit set and number of flowers in 'Brazilian seedless' sugar apple that were pollinated naturally, artificially and by selfing

\begin{tabular}{lcc}
\hline Pollination mode & $\begin{array}{c}\text { Percentage of } \\
\text { fruit set }\end{array}$ & $\begin{array}{c}\text { Number of flowers } \\
\text { pollinated }\end{array}$ \\
\hline Natural Pollination & 90 & 30 \\
Artificial Pollination & 100 & 30 \\
Self-Pollination & 0 & 30 \\
\hline
\end{tabular}

Significant differences in pollen germination were observed between the genotypes that were evaluated (Table 2). The average pollen germination rate was highest in pollen grains collected from 'Brazilian seedless' (52.5\%), while 'Gefner' presented $5.9 \%$ of pollen germination (Table 2). The results of a previous study conducted in the same region with seeded sugar apple were similar. Pollen germination of sugar apple accession ranged from $46.75 \%$ to $53.62 \%$ (Nietsche et al. 2009). Bettiol Neto et al. (2009) found germination rates of $19.70 \%$ and $26.24 \%$, respectively, for pollen grains from flowers of 'Gefner' and sugar apple. According to Saavedra (1977) Annona pollen presented a good proportion of dyads and tetrads intermingled among individual viable and non-viable pollen grains, and the tetrads were incapable of germinating on the stigmatic surface in cherimoya. The authors conclude that the high concentration of tetrads observed in atemoya is probably due to their interspecific constitution. Judd (2007) also reported that the viability of pollen grains is affected by variations in moisture and temperature, and can be assessed by testing germination, enzymatic activity, and the presence of cytoplasm.

The preliminary results of this study suggest that seedlessness in 'Brazilian seedless' sugar apple is associated to the mechanism of stenospermy and that the pollen grains are fully fertile. Although seedless sugar apple cultivars are not widely grown, the presence of this trait in Annona could dramatically increase the popularity of this species for human consumption (Lora et al. 2011).

\section{ACKNOWLEGDEMENTS}

The authors thank Fundação de Amparo à Pesquisa do Estado de Minas Gerais (FAPEMIG) and Conselho Nacional de Desenvolvimento Científico e Tecnológico (CNPq) for supporting this work.

\section{Germinação de grãos de pólen e formação de frutos em fruta do conde (Annona squamosa L.)}

Resumo - O presente estudo foi desenvolvido visando avaliar a formação de frutos e germinação de grãos de pólen em pinheira 'Brazilian seedless'. Dois experimentos foram realizados: 1) delineamento inteiramente casualizado com três tratamentos (polinização natural, artificial e autopolinização), com três repetições e dez flores por parcela; 2) delineamento inteiramente casualizado com três tratamentos (grãos de pólen de pinheira com semente, ‘Brazilian seedless〉 e atemóia, híbrido entre pinheira (Annona squamosa) e cherimóia (Annona cherimola) 'Gefner'), cinco repetições. Foi observado $100 \%$ de formação de frutos por meio da polinização artificial. Não foi observada a formação de frutos por meio da autopolinização. A porcentagem de germinação in vitro de grãos de pólen foi maior em 'Brazilian seedless' (52,5\%) e menor na cultivar 'Gefner (5,9\%). Resultados preliminares indicam que grãos de pólen da 'Brazilian seedless'são viáveis e polinização artificial ou natural são essenciais para a produção de frutos.

Palavras-chave: Fruto sem semente, atemóia e polinização artificial.

\section{REFERENCES}

Bettiol Neto JE, Del Nero M, Kavati R and Pinto-Maglio CAF (2009) Viabilidade e conservação de pólen de três Anonas comerciais. Bragantia 68: 825-837.

Brewbaker JL and Kwack BH (1963) The essential role of calcium ion in pollen germination and pollen tube growth. American Journal of Botany 50: 859-865.

Cavalcante TRM, Naves RV, Franceschinelli EV and Silva RP da (2009) Polinização e formação de frutos em araticum. Bragantia 68: 13-21.

Crane JH, Balerdi CF and Maguire I (2005) Sugar apple growing in the
Florida home landscape. Horticultural Sciences Department Fact Sheet HS38. Florida Cooperative Extension Service, Institute of Food and Agricultural Sciences, University of Florida. Tropical Research and Education Center, Homestead, 9p.

Duarte O and Escobar O (1998) Improving fruit set of cherimoya (Annona cherimola Mill.) cv. Cumbe, by autogamous and allogamous hand pollination. Proceedings Interamerican Society for Tropical Horticulture 41: 162-165.

Euclydes RF (1983) Manual de utilização do programa SAEG (Sistema para Análises Estatísticas e Genéticas). Universidade Federal de Viçosa, Viçosa, 150p. 
HTA Mendes et al.

Judd WS, Campbell CS, Kellog EA, Stevens PF and Donahue M J (2007) Plant systematic: a phylogenetic approach. $3^{\text {rd }}$ ed., Sinauer Associates, Sunderland, 565p.

Kahn TL, Adams CJ and Arapaia ML (1994) Paternal and maternal effects on fruit and seed characteristics in cherimoya (Annona cherimola Mill.).Scientia Horticulturae 59: 11-25.

Kishirsagar SV, Shinde NN, Rane DA and Borikar ST (1976) Studies on the floral biology in atemoya (Annona cherimola x Annona squamosa). South Indian Horticulture 24: 6-10.

Lora J, Hormaza JI, Herrero M and Gasser CS (2011) Seedless fruits and the disruption of a conserved genetic pathway in angiosperm ovule development. Proceedings of the National Academy of Sciences of the United States of America 108: 5461-5465.

Melo MR, Pommer CP and Kavati R (2002) Polinização artificial da atemóia com diversas fontes de pólen comparada com a natural. Bragantia 61: 231-236.

Nietsche S, Pereira MCT, Oliveira C, Dias MM and Reis ST (2009) Viabilidade dos grãos de pólen de flores de pinheira (Annona squamosa L.) em diferentes horários. Ciência e Agrotecnologia 33: $527-531$.

Peña JE, Nadel H, Barbosa-Pereira M and Smith D (2002) Pollinators and pests of Annona species. In Peña JE, Sharp JL and Wysoki M (eds) Tropical fruit pests and pollinators. CAB, United Kingdom, p. 197-221.

Pereira MCT, Nietsche S, Santos FS, Xavier AA, Cunha LMV, Nunes CF and Santos FA (2003) Efeito de horários de polinização artificial no pegamento e qualidade de frutos de pinha (Annona squamosa L.). Revista Brasileira de Fruticultura 25: 203-205.
Revers LF, Lampe VS, Oliveira PRD, De Camargo UA and Lima JC (2006) Uso prático de marcadores moleculares para seleção assistida no melhoramento de uvas de mesa apirênicas. Revista Brasileira de Fruticultura 28: 104-108.

Richardson AC and Anderson PA (1996) Hand pollination effects on the set and development of cherimoya (Annona cherimola) fruit in a humid climate. Scientia Horticulturae 65: 273-281.

Rosell P, Herrero M and Galan Sauco (1999) Pollen germination of cherimoya (Annona cherimola Mill.). In vivo characterization and optimization of in vitro germination. Scientia Horticulturae 81: 251-265.

Saavedra E (1977) Influence of pollen grain stage at the time of hand pollination as a factor on fruit set of cherimoya. Hortscience 12: 117-118.

Soria JT, Hermoso JM and Farre JM (1990) Polinización artificial del chirimoyo. Fruticultura Professional 35: 15-22.

Souza DA, Melo LC, Librelon SS, Costa MR, Nietsche S and Pereira MCT (2010) Identification of hybrids of intra and interspecific crosses in Annonaceae by RAPD markers. Crop Breeding and Applied Biotechnology 10: 110-115.

Stout AB (1936) Seedlessness in grapes. New York State Agriculture, Technical Bulletin New York 238.

Sulikeri GS, Nalawadi UG and Singh CD (1975) Pollen viability studies in Annona squamosa L. Current Research 4: 31-32.

Varoquaux F, Blanvillain R, Delseny M and Gallois P (2000) Less is better: new approaches for seedless fruit production. Tibtech 18: 235-242. 